\title{
E-Surveilans Bloodstream Infection pada Pasien di Nitipuran Health Centre
}

\author{
Nungky Kescandra ${ }^{1}$, Elsye Maria Rosa ${ }^{2}$, Sri Sundari ${ }^{3}$ \\ ${ }^{1.2 .3}$ Magister Manajemen Rumah Sakit, Pascasarjana, Universitas Muhammadiyah Yogyakarta \\ Jl.Brawijaya, Taman tirto Kasihan Bantul, 55183 \\ Correspondence e-mail: nungky_7@hotmail.com)
}

\begin{abstract}
Abstrak. Penyakit infeksi masih menjadi salah satu masalah kesehatan di dunia, termasuk Indonesia. Tujuan penelitian ini adalah mengetahui kejadian Bloodstream Infection dengan menggunakan e-surveilans di Nitipuran Health Centre. Penelitian ini menggunakan mixed method dengan pendekatan Cohort Study. Subjek penelitian adalah pasien yang melakukan hemodialisa sebagai data kuantitatif dan dokter, perawat dan kepala perawat sebagai data kualitatif. Analisis data kuantitatif dengan analisis deskriptif, dan analisis kualitatif dengan wawancara lebih mendalam. Diketahui kejadian Bloodstream Infection dengan menggunakan e-surveilans di Klinik NHC sebanyak 4 kasus. Dan keempat kasus tersebut positif mengandung bakteri. Faktorfaktor yang mempengaruhi Bloodstream Infection di Klinik Hemodialisa Nitipuran adalah kesadaran tenaga medis untuk menjga kebersihan diri masih kurang dan kepatuhan tenaga medis untuk melakukan SOP PPI masih rendah. Pencegahan terjadinya Bloodstream Infection di NHC perlu ditingkatkan dengan melakukan sosialisasi mengenai SOP Pencegahan dan Pengendalian Infeksi (PPI), membentuk suatu tim khusus untuk mengawasi jalannya SOP PPI dan meningkatkan kesadaran diri tentang hand hygiene.
\end{abstract}

Kata kunci: bloodstream infection; e-surveilans; hemodialisis

\begin{abstract}
Infectious disease is still one of the health problems in the world, including Indonesia. The purpose of this study was to determine the occurrence of Bloodstream Infection using e-surveillance at Nitipuran Health Center. This study uses a mixed method with the Cohort Study approach. Research subjects were patient who did hemodialysis for quantitative data and doctors, nurses and head nurses for qualitative data. Quantitative data analysis with descriptive analysis, and qualitative analysis with indepth interviews. Result: Four cases of Bloodstream Infection were identified using e-surveillance in NHC. And 4 cases is positive containing bacteria. Factors affecting Bloodstream Infection at the Nitipuran Hemodialysis Clinic are the awareness of medical personnel to keep personal hygiene still lacking and the compliance of medical personnel to perform SOP PPI is still low. Conclusion: Prevention of Bloodstream Infection in NHC needs to be improved by socialization on SOP for Prevention and Infection Control (PPI), forming a special team that is tasked with supervising the running of PPI SOPS and familiarizing themselves with maintaining hand hygiene.
\end{abstract}

Keywords: bloodstream infection; e-surveillance; hemodialysis

\section{PENDAHULUAN}

Penyakit infeksi masih menjadi salah satu masalah kesehatan di dunia, termasuk Indonesia. Apabila dilihat dari penyebab terjadinya maka infeksi dapat berasal dari komunitas (Community Acquired Infection) atau dari lingkungan rumah sakit (Hospital Acquired Infection) yang sebelumnya lebih dikenal dengan infeksi nosoklomial.

Seringkali infeksi yang terjadi tidak dapat ditentukan asalnya secara pasti, maka untuk saat ini istilah infeksi nosokomial (Hospital acquired infection) digantikan dengan istilah yang baru yaitu "Healthcareassociated infections" (HAIs) dengan pengertian yang lebih luas karena tidak hanya terbatas pada rumah sakit tetapi juga di fasilitas pelayanan kesehatan lainnya. HAIs meliputi Infeksi yang terjadi pada pasien dan juga pada petugas kesehatan yang diperoleh pada saat melakukan perawatan terhadap pasien (Kemenkes, 2011).

Bloodstream Infection atau Infeksi Aliran Darah Primer (IADP) adalah infeksi yang timbul tanpa ada organ atau jaringan lain yang dicurigai sebagai sumber infeksi.Surveilans kesehatan merupakan kegiatan pemantauan yang dilakukan secara terus-menerus dan sistematis terhadap data dan informasi mengenai masalah kesehatan untuk memperoleh serta memberikan informasi mengenai masalah kesehatan untuk memperoleh serta memberikan informasi yang dapat digunakan sebagai pembuatan program dalam tindakan pencegahan dan penanggulangan secara efektif dan efisien. Kegiatan surveilans terdiri dari pengumpulan data, kompilasi data, analisis data, interpretasi data, dan diserminasi informasi. Kegiatan surveilans tersebut juga dapat digunakan sebagai bahan evaluasi suatu program yang telah atau akan berjalan dalam pengendalian dan pencegahan suatu kejadian (Vebrilian, 2007).

Bloodstream infection atau infeksi aliran darah primer (IADP) adalah infeksi yang timbul tanpa ada organ atau jaringan lain yang dicurigai sebagai sumber infeksi. Infeksi ini, sering digunakan sebagai salah satu sumber data digunakan untuk mengendalikan infeksi nosokomial (IN) di rumah sakit. Menurut (Surasmi, Asrining, 2003) ada beberapa definisi dari bloodstream infection yaitu Primary Bloodstream Infection (BSI), Secondary Bloodstream Infection, Kolonisasi, Bakterimia dan Sepsis. 
Kriteria Bloodstream Infection untuk Dewasa \& Anak $>12$ bulan, jika ada salah satu atau lebih dari Suhu $>38^{\circ} \mathrm{C}$, bertahan $\geq 24$ jam, Hipotensi, sistolik $<90$ $\mathrm{mmHg}$, Oliguria, jumlah urine $<0,5 \mathrm{cc} / \mathrm{kgBB} / \mathrm{jam}$, Terdapat kontaminasi kulit dari 2 (dua) biakan berturut turut, Telah diberi antibiotik sesuai sepsis. Untuk bayi < 12 bulan, jika terdapat salah satu atau lebih dari Demam $>38^{\circ} \mathrm{C}$, Hipotermi, Apnea, dan Bradikardi< 100x/menit.

Surveilans BSI adalah pengumpulan data kejadian infeksi aliran darah akibat penggunaan alat intravaskuler secara sistematis, analisis dan interpretasi yang terus menerus untuk digunakan dalam perencanaan, penerapan dan evaluasi suatu tindakan yang berhubungan dengan kesehatan yang di desiminasikan secara berkala kepada pihak-pihak yang memerlukan (Perdalin, 2014).

Hemodialisa adalah salah satu terapi pengganti ginjal yang menggunakan alat khusus dengan tujuan mengeluarkan toksin uremik dan mengatur cairan elektrolit tubuh. Unit pelayanan dialisis adalah fasilitas pelayanan dialisis di rumah sakit (Kemenkes, 2010). Penelitian ini hanya dilakukan pada pasien yang menjalani perawatan hemodialisa di klinik NHC.

Tujuan penelitian ini adalah untuk: Mengevaluasi kejadian Bloodstream Infection pada unit hemodialisis di Nitipuran Health Centre. Mengetahui faktor-faktor yang mempengaruhi Bloodstream Infection di Nitipuran Health Centre. Menyusun rekomendasi guna pencegahan terjadinya Bloodstream Infection di Nitipuran Health Centre.

\section{METODE}

Penelitian ini merupakan penelitian deskriptif analitik non eksperimental dengan menggunakan rancangan mix method dengan pendekatan Cohort Study. Data diperoleh dengan cara kuantitatif yaitu peneliti melakukan penelitian lapangan (field research) yaitu observasi langsung kepada pasien yang melakukan hemodialisis di NHC dalam periode waktu yang telah ditentukan. Data kualitatif diperoleh dengan cara deep interview yang bertujuan untuk mengetahui faktor-faktor yang menyebabkan infeksi.

Penelitian ini dilakukan di Nitipuran Health Centre, yang beralamat di Jl. Nitipuran No. 183 B, RT 06 Dukuh Sonosewu Kelurahan Ngestiharjo Kecamatan Kasihan, Kabupaten Bantul, DIY. Pada penelitian dari segi data kuantitatif adalah rekam medis pasien yang menjalani hemodialisis, sedangkan dari segi data kualitatif adalah perawat, kepala perawat dan dokter.

Objek penelitian ini adalah kejadian bloodstream infection di Nitipuran Health Centre. Pada penelitian ini peneliti menggunakan instrumen Electronic Surveillance System (ESS) yaitu https://pku-gamping.umyesurveilence.comdi RS PKU Muhammadiyah Gamping. Instrumen penelitian yang digunakan dalam pendekatan kuantitatif adalah sebagai berikut: Lembar wawancara yang merupakan daftar pertanyaan yang akan diajukan kepada informan penelitian. Alat perekam, yaitu alat yang digunakan untuk merekam hasil wawancara yang dilakukan kepada informan penelitian.

Secara garis besar pada penelitian ini dilakukan tiga proses pengumpulan datayaitu telusur dokumen, observasi, dan wawancara yang dilakuakan sesuai dengan panduan masing-masing. Dilakukan dengan analisis deskriptif terhadap telusur dokumen dan observasi untuk mengetahui kejadian bloodstream infection pada pasien rawat jalan hemodialisis yang terjadi oleh beberapa faktor, antara lain: hand hygiene, teknik pemasangan, antiseptik, fiksasi. Menghitung laju infeksi menggunakan rumus dari Kementrian Kesehatan Republik Indonesia (Kemenkes, 2011) tentang pedoman surveilans infeksi.

Setelah dilakukan semua tahapan mulai dari pengumpulan data, telusur dokumen dan observasi, maka data akan diinput ke dalam e-surveilans di https://pku-gamping.umy-esurveilence.com. Setelah semua data diinput ke dalam e-surveilans maka data akan di analisa ke dalam grafik hasil infeksi.

Hasil pelaksanaan analisis kejadian bloodstream infection pada pasien hemodialisis yang diteliti oleh peneliti dan disesuaikan dengan situasi dan kondisi yang sebenarnya dengan melakukan wawancara lebih mendalam untuk melihat faktor-faktor apa saja yang mempengaruhi terjadinya infeksi. meliputi Pengumpulan Data, Data disajikan dalam bentuk naratif, reduksi, coding, dan tema, serta kesimpulan.

\section{HASIL DAN PEMBAHASAN \\ Hasil}

Kepatuhan dan Ketepatan Assessment Pre Dialisis

Tabel 1. Karakteristik Responden

\begin{tabular}{clcc}
\hline No & \multicolumn{1}{c}{ Karakteristik } & f & \% \\
\hline 1 & Jenis Kelamin & & \\
& a.Pria & 80 & 52,6 \\
& b. Wanita & 72 & 47,4 \\
& Jumlah & 152 & 100,0 \\
2 & Usia & & \\
& a. $<30$ tahun & 8 & 5,3 \\
& b. $30-60$ tahun & 94 & 61,8 \\
& c. $>60$ tahun & 50 & 32,9 \\
& Jumlah & 152 & 100,0 \\
Diagnosis & & \\
& a. CKD Stage V & 152 & 100,0 \\
& Jumlah & 152 & 100,0 \\
\hline
\end{tabular}

Berdasarkan tabel 1 diatas menunjukkan bahwa karakteristik pasien berdasarkan jenis kelamin, sebagian besar pria sebanyak $52,6 \%$, berdasarkan umur, sebagian besar responden berumur 30-60 tahun sebanyak 61,8\%, dan paling sedikit dibawah 30 tahun sebanyak 5,3\%. Berdasarkan diagnosis, $100 \%$ responden didiagnosis CKD stage IV. 


\section{Karakteristik sample}

Tabel 2. Karakteristik sample

\begin{tabular}{clcc}
\hline No & \multicolumn{1}{c}{ Karakteristik } & f & \% \\
\hline 1 & Jenis Kelamin & & \\
& a. Pria & 2 & 50,0 \\
& b. Wanita & 2 & 50,0 \\
& Jumlah & 4 & 100,0 \\
2 Usia & & \\
& a. $<30$ tahun & 1 & 25,0 \\
& b. $30-60$ tahun & 2 & 50,0 \\
& c. $>60$ tahun & 1 & 25,0 \\
& Jumlah & 4 & 100,0 \\
\hline
\end{tabular}

Tabel 2 menunjukkan bahwa karakteristik sample berdasarkan jenis kelamin, pria sebanyak $50,0 \%$ dan wanita sebanyak $50 \%$, berdasarkan umur, responden berusia $<30$ tahun sebanyak $25,0 \%$, responden berumur 30-60 tahun sebanyak 50,0\%, dan dibawah 30 tahun sebanyak $25,0 \%$.

Tabel 3. Siklus HD

\begin{tabular}{ccccc}
\hline No & Pasien & HD ke & Alat Terpasang & Bakteri \\
\hline 1 & Pasien 1 & 5 & CVC+AV shunt & Pseudomonas Aenginosa \\
& Pasien 2 & 11 & AV shunt & Burkholderia Cepacia \\
& Pasien 3 & 6 & CVC+AV shunt & Pseudomonas Aenginosa \\
& Pasien 4 & 15 & CVC+AV shunt & Pseudoonas Luteola, \\
& & & Staphylococcus koagulase negatif \\
\hline
\end{tabular}

Tabel 3 menunjukkan bahwa dari keempat sample yang diperiksa, pasien 1 menunjukkan gejala infeksi pada saat siklus HD ke 5 dan terpasang CVC dan AV shunt dan pada saat diuji kultur darah menunjukan hasil positif bakteri Pseudomonas Aeruginosa. Pada pasien 2 menunjukkan gejala infeksi pada saat siklus HD ke 11 dan terpasang AV shunt dan pada saat diuji kultur darah menunjukan hasil positif bakteri Burkholderia Cepacia. pasien 3 menunjukkan gejala infeksi pada saat siklus HD ke 6 dan terpasang CVC dan AV shunt dan pada saat diuji kultur darah menunjukan hasil positif bakteri Pseudomonas Aeruginosa. pasien 4 menunjukkan gejala infeksi pada saat siklus HD ke 15 dan terpasang CVC dan AV shunt dan pada saat diuji kultur darah menunjukan hasil positif bakteri Pseudomonas Luteola dan Staphylococcus koagulase negatif.

\section{Kejadian Bloodstream Infection di NHC}

Kejadian Bloodstream Infection diperoleh dari hasil pemeriksaan terhadap pasien yang melakukan HD di Klinik Hemodialisa Nitipuran. Dari hasil pemeriksaan terhadap 4 pasien yang diambil secara acak, menunjukkan bahwa keempat pasien tersebut positif mengalami Bloodstream Infection. Hasil selengkapnya dapat dilihat pada grafik kejadian Bloodstream Infection di bawah ini.

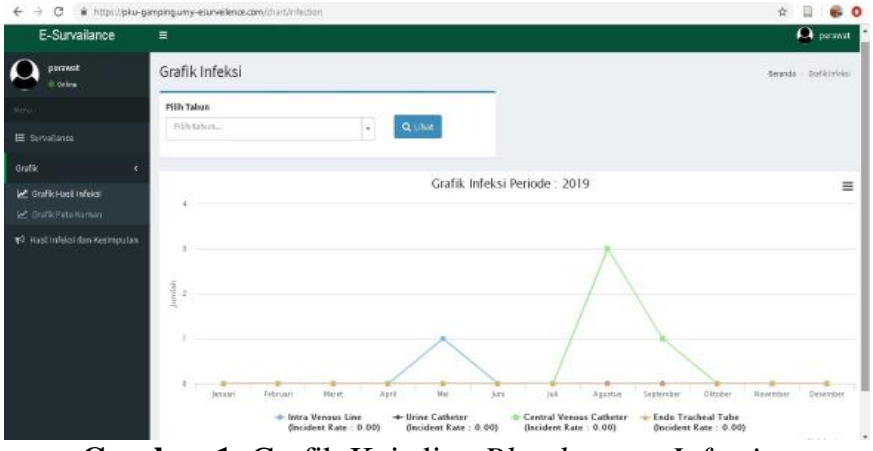

Gambar 1. Grafik Kejadian Bloodstream Infection

Gambar di atas menunjukkan bahwa selama bulan April sampai Oktober 2019 terdapat 4 kasus Bloodstream Infection. Jenis bakteri yang terdeteksi pada ke empat pasien tersebut antara lain Pseudomonas luteola, Pseudomonas aeruginosa, Staphylococcus koagulase negatif dan Burkholderia cepacia. Keempat pasien tersebut terdeteksi mengalami Bloodstream Infection setelah menjalani pemeriksaan kultur.

\section{Faktor-Faktor yang Mempengaruhi Bloodstream Infection Di Klinik Hemodialisa Nitipuran}

Tabel 4. Deskripsi Pengertian Bloodstream Infection

\begin{tabular}{lcl}
\hline \multicolumn{1}{c}{ Tema } & Kode & \multicolumn{2}{c}{ Interpretasi } \\
\hline $\begin{array}{l}\text { Pengertian } \\
\text { Bloodstream }\end{array}$ & $\mathrm{D}$ & $\begin{array}{l}\text { Infeksi yang terjadi melalui } \\
\text { darah }\end{array}$ \\
Infection & $\mathrm{Pr}$ & $\begin{array}{l}\text { infeksi di dalam darah pasien } \\
\end{array}$ \\
& Ka.Pr & $\begin{array}{l}\text { Infeksi yang ditularkan } \\
\text { melalui darah }\end{array}$ \\
\hline
\end{tabular}

Berdasarkan hasil tabel di atas, menunjukkan bahwa dokter, perawat dan kepala perawat Klinik Hemodialisa Nitipuran menyatakan bahwa Bloodstream Infection merupakan infeksi yang terjadi dalam darah.

Tabel 5. Deskripsi Gejala Bloodstream Infection

\begin{tabular}{lcl}
\hline \multicolumn{1}{c}{ Tema } & Kode & \multicolumn{1}{c}{ Interpretasi } \\
\hline Gejala & $\mathrm{D}$ & infeksi lokal dan sistemik \\
Bloodstream & $\mathrm{Pr}$ & demam, menggigil \\
Infection & Ka.Pr & tergantung yang menginfeksi \\
\hline
\end{tabular}

Berdasarkan hasil tabel di atas, menunjukkan bahwa dokter, perawat dan kepala perawat Klinik Hemodialisa Nitipuran menyatakan bahwa penyebab Bloodstream Infection itu, tergantung pada infektan yang menginfeksinya, namun umumnya disertai demam dan menggigil.

Tabel 6. Deskripsi Faktor Penyebab Bloodstream Infection

\begin{tabular}{lcl}
\hline \multicolumn{1}{c}{ Tema } & Kode & \multicolumn{2}{c}{ Interpretasi } \\
\hline faktor $\quad$ penyebab & $\mathrm{D}$ & kebersihan diri yang \\
Bloodstream Infection & & $\begin{array}{l}\text { kurang, luka kurang } \\
\text { terawat } \\
\text { perilaku dari tenaga } \\
\end{array}$ \\
& $\mathrm{Pr}$ & $\begin{array}{l}\text { medis } \\
\text { perilaku petugas }\end{array}$ \\
& $\mathrm{Ka.Pr}$
\end{tabular}


Berdasarkan hasil tabel di atas, menunjukkan bahwa dokter, perawat dan kepala perawat Klinik Hemodialisa Nitipuran menyatakan bahwa faktor-faktor yang menjadi penyebab Bloodstream Infection antara lain kebersihan diri yang kurang dan perilaku dari tenaga medis yang memandang rendah kebersihan.

Tabel 7. Deskripsi SOP Pencegahan dan Pengendalian Infeksi

\begin{tabular}{ccl}
\hline Tema & Kode & \multicolumn{1}{c}{ Interpretasi } \\
\hline SOP PPI & $\mathrm{D}$ & SOP sudah ada \\
& Pr & SOP sudah ada \\
& Ka.Pr & SOP sudah ada \\
\hline
\end{tabular}

Berdasarkan hasil tabel di atas, menunjukkan bahwa dokter, perawat dan kepala perawat Klinik Hemodialisa Nitipuran menyatakan bahwa SOP suudah ada.

Tabel 8. Deskripsi Implementasi SOP Pencegahan dan Pengendalian Infeksi

\begin{tabular}{lcl}
\multicolumn{1}{c}{ Tema } & Kode & \multicolumn{1}{c}{ Interpretasi } \\
\hline Implementasi & $\mathrm{D}$ & sudah cukup baik \\
SOP PPI & $\mathrm{Pr}$ & cukup baik \\
& Ka.Pr & sudah diimplementasikan \\
\hline
\end{tabular}

Berdasarkan hasil tabel di atas, menunjukkan bahwa dokter, perawat dan kepala perawat Klinik Hemodialisa Nitipuran menyatakan bahwa implementasi SOP pencegahan dan pengendalian infeksi sudah cukup baik.

Tabel 9. Deskripsi Kendala SOP Pencegahan dan Pengendalian Infeksi

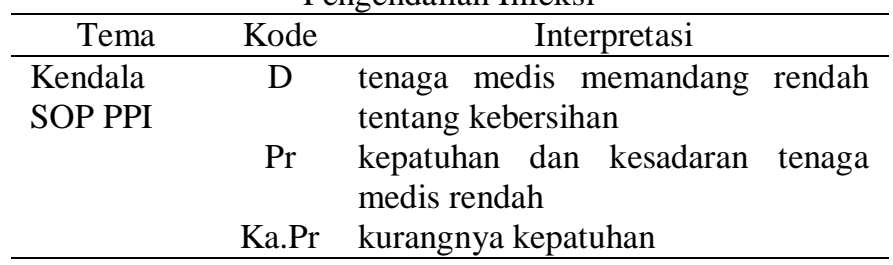

Berdasarkan hasil tabel di atas, menunjukkan bahwa dokter, perawat dan kepala perawat Klinik Hemodialisa Nitipuran menyatakan bahwa kendala yang dihdapi dalam melaksanakan SOP PPI antara lain:

1. tenaga medis memandang rendah tentang kebersihan

2. kepatuhan dan kesadaran tenaga medis rendah

3. kurangnya kepatuhan

Tabel 10. Deskripsi Harapan Pencegahan dan Pengendalian Infeksi

\begin{tabular}{|c|c|c|}
\hline Tema & Kode & Interpretasi \\
\hline Harapan PPI & $\mathrm{D}$ & $\begin{array}{l}\text { tidak ditemukan lagi Bloodstream } \\
\text { Infection }\end{array}$ \\
\hline & $\begin{array}{c}\mathrm{Pr} \\
\mathrm{Ka} \cdot \mathrm{Pr}\end{array}$ & $\begin{array}{l}\text { meminimalkan terjadinya infeksi } \\
\text { kebersihan lebih dijaga lagi }\end{array}$ \\
\hline
\end{tabular}

Berdasarkan hasil tabel di atas, menunjukkan bahwa dokter, perawat dan kepala perawat Klinik
Hemodialisa Nitipuran memiliki harapan agar tidak ditemukan lagi Bloodstream Infection, meminimalkan terjadinya infeksi dan kebersihan lebih dijaga lagi.

\section{Pembahasan}

Hasil penelitian menunjukkan bahwa selama bulan April sampai Oktober 2019 terdapat 4 kasus Bloodstream Infection di Klinik Hemodialisa Nitipuran. Bloodstream infection atau infeksi aliran darah primer (IADP) adalah infeksi yang timbul tanpa ada organ atau jaringan lain yang dicurigai sebagai sumber infeksi Penyebab infeksi pada pasien Penyakit Ginjal Kronis (PGK) adalah menurunnya sistem imun, adanya penyebab sekunder (diabetes, penyakit jantung, dan lainlain) yang pada akhirnya memperberat risiko infeksi (Loho \& Pusparini, 2000). Selain itu, infeksi pada pasien hemodialisis dapat disebabkan karena prosedur pemasangan dan insersi akses vaskuler hemodialysis (Moist, 2008), infeksi karena kerentanan pasien PGK (Erika,.et al. 2000), dan Infeksi karena Komponen Hemodialisis (Daugirdas., et al, 2007).

Menurut hasil penelitian, pada bulan Agustus 2019 tercatat sebanyak 152 pasien yang melakukan hemodialisa, terdapat 4 pasien yang memenuhi kriteria inklusi dan dilakukan uji kultur darah. Hasil kultur darah menunjukkan keempat pasien tersebut positif mengandung bakteri. Oleh karena itu menurut Kemenkes (2011) tentang kriteria bloodstream infection, keempat pasien tersebut dapat dinyatakan mengalami bloodstream infection. Dan diketahui laju infeksi pada bulan Agustus 2019 sebesar 26,3\%. Pada hasil uji kultur darah, didapatkan 4 jenis bakteri yang terdeteksi, yaitu Pseudomonas luteola, Staphylococcus koagulase negatif, Pseudomonas aeruginosa dan Burkholderia cepacia. Menurut penelitian Masahi Suzuki (2016), terdapat beberapa jenis bakteri yang biasa dijumpai pada pasien yang melakukan hemodialisa, antara lain, bakteri gram positif (Staphylococcus aureus, streptococcus, enterococcus) dan gram negatif (E. coli, Pseudomonas Aeruginosa, Enterobacter, Klebsiella, Candida). Hal ini sesuai dengan hasil penelitian bahwa terdapat 2 pasien yang menunjukkan positif bakteri pseudomonas aeruginosa. Dan terdapat 1 pasien dengan bakteri teridentifikasi Staphylococcus koagulase negatif yang sesuai dengan kriteria kedua dari bloodstream infection. Namun kedua jenis bakteri lainnya tidak biasa dijumpai pada pasien hemodialisis.

Hasil penelitian ini menunjukkan bahwa faktorfaktor yang mempengaruhi Bloodstream Infection di klinik Hemodialisa Nitipuran adalah kebersihan diri yang kurang dan perilaku dari tenaga medis yang memandang rendah kebersihan. Hasil wawancara menunjukkan bahwa masih ditemukan beberapa tenaga medis yang menggunakan 1 handscoon untuk beberapa pasien, padahal seharusnya 1 handscoon untuk 1 pasien. Selain itu, perilaku mencuci tangan yang dilakukan tenaga medis belum sesuai dengan ketentuan dari WHO. 
Faktor-faktor tersebut diduga menjadi penyebab munculnya Bloodstream Infection di klinik Hemodialisa Nitipuran. Oleh karena itu, untuk mencegah agar tidak terjadi lagi Bloodstream Infection, perlu dilakukan beberapa langkah pencegahan.

Rekomendasi untuk pencegahan terjadinya Bloodstream Infection adalah dengan penyegaran atau sosialisasi mengenai SOP Pencegahan dan Pengendalian Infeksi (PPI), dimana selama ini di Klinik Hemodialisa Nitipuran masih kurang. Selain itu bisa dilakukan dengan membentuk suatu tim khusus yang bertugas untuk mengawasi jalannya SOP PPI. Selanjutnya adalah mulai membiasakan diri untuk menjaga kebersihan dengan cara menggunakan 1 handscoon untuk 1 pasien, dan menyediakan tempat sampah pada setiap bed.

\section{SIMPULAN}

Berdasarkan hasil penelitian dan pembahasan, dapat ditarik kesimpulan sebagai berikut: Diketahui kejadian Bloodstream Infection dengan menggunakan esurveilans di Klinik Hemodialisa Nitipuran sebanyak 4 kasus. Faktor-faktor yang mempengaruhi Bloodstream Infection di Klinik Hemodialisa Nitipuran adalah: Kesadaran tenaga medis untuk menjga kebersihan diri masih kurang. Kepatuhan tenaga medis untuk melakukan SOP PPI masih rendah.

Rekomendasi pencegahan terjadinya Bloodstream Infection adalah: Melakukan penyegaran atau sosialisasi mengenai SOP Pencegahan dan Pengendalian Infeksi (PPI). membentuk suatu tim khusus yang bertugas untuk mengawasi jalannya SOP PPI. mulai membiasakan diri untuk menjaga kebersihan, misalnya dengan cara menggunakan 1 handscoon untuk 1 pasien, dan menyediakan tempat sampah pada setiap bed.

\section{DAFTAR PUSTAKA}

Daugirdas., J, T.,Blake, P, G.,\& Ing, T, S. (2007) Handbook Of Dialysis 4th Edition. Philadelphia. Lippincott Williams \& darmadiWilkins

Erika,. M.C. D’Agata., David B. Mount., Valerie T., \& William S. (2000). Hospital-Acquired Infections Among Chronic Hemodialysis Patients. AmericanJournal of Kidney Diseases, Vol 35, No $6:$ pp 1083-1088

Kementerian Kesehatan RI. 2011. Pedoman Pencegahan dan Pengendalian Infeksi di Rumah Sakit dan Fasilitas Pelayanan Kesehatan Lainnya. PERDALIN : Jakarta.

Loho, T.,\& Pusparini. (2000). Infeksi nosokomial pada hemodialisis. Majalah

Moist, L. M., Trpeski, L., Na, Y. \& Lok, C. E.(2008) Increased hemodialysis catheter use in Canada and associated mortality risk: data from the Canadian organ replacement registry 2001-2004. Clin. J. Am. Soc.Nephrol. 3, 1726-1732

Perdalin, 2014. Seminar dan Workshop PPI: Surveilans Infeksi Aliran Darah Primer
Surasmi, Asrining, (2003). Perawatan Bayi Resiko Tinggi. Jakarta : EGC

Vebrilian, S.R. (2017) Surveilans Catheter Associated Urinary Tract Infection Berdasarkan Atribut Surveilans Di RSU Haji Surabaya. Departemen Epidimiologi Fakultas Kesehatan Airlangga. Journal Berkala Epidimiologi. Volume 4 No. 3. doi : 10.20473/jbe.v4i3 